\title{
Nautinnollisia ääniä. Lacanilainen tulkinta Jane Campionin elokuvasta Piano
}

Tutkin Jane Campionin elokuvaa Piano (1992) lacanilaisen psykoanalyysin avulla. Keskityn lähinnä siihen, kuinka lacanilainen nautinto (jouissance) ilmenee elokuvassa erilaisten äänielementtien ja musiikin avulla. En kuitenkaan pyri analysoimaan kaikkia elokuvan ääniraitaan liittyviä aspekteja. Elokuvallisen aika-avaruuden muutokset nautinnon hetkinä saavat myös osansa. Lähinnä tulkitsen sitä, miten nautinto ilmenee elokuvan henkilöhahmojen teoissa ja niiden vaikutuksissa sekä elokuvan äänissä. Pohdiskelen myös sitä, kuinka elokuvan kokija saattaa suhtautua kokemaansa ja kuinka hän voi kenties kokea nautintoa.

Aluksi erittelen joitakin tutkimukseni kannalta keskeisiä lacanilaisen psykoanalyysin käsitteitä. Tämän jälkeen tarkastelen nk. mustien aukkojen avulla sitä, kuinka tilan ja ajan suhteita ja erityisesti niiden vääristymiä on mahdollista lähestyä Lacanin teorioiden pohjalta. Luvussa "Adan ääni" kartoitan päähenkilön suhdetta pianoon ja sen sointiin sekä Adan sisäisen puheen problematiikkaa. Tätä seuraa tulkintaa eräästä, lähinnä taustaääneksi lukeutuvasta elementistä. Lopuksi pohdin pääasiassa elokuvan kahden tärkeimmän teeman suhdetta henkilöhahmoihin, nautintoon ja elokuvalliseen aika-avaruuteen.

\section{Lacanilaisen psykoanalyysin peruskäsitteitä}

Jacques Lacanin mukaan todellisuus, jossa elämme on symbolisen järjestyksen tai lyhyemmin symbolisen (symbolique) universumi. Veijo Hietalan (1990b, 19) mukaan Lacan tarkoittaa symbolisella kulttuurin käsitteitä käyttävää systeemiä, jonka selkein esiintymä on kieli. Kielen käsite on hänen mukaansa ymmärrettävä lacanilaisessa kontekstissa "verbaalista kommunikaatiosysteemiä laajemmin objektien ja käsitteiden erot mahdollistavana systeeminä, jossa myös visuaaliset [ja auditiiviset] ilmaisut ovat mukana sen jälkeen kun ne on 'nimetty"' (Hietala 1990a, 231). Lacanille symbolinen on tavallaan sekä yksi että monta. Kielen maailma koostuu monista symbolisista systeemeistä [symbolic systems]. Näitä ovat mm. uskonnolliset, lakia säätävät, tieteelliset ja po- 
liittiset systeemit, jotka eivät ole yhteneviä, vaan niiden välillä on eroja ja virheitä. Ihmiset ovat uppoutuneita moniin tällaisiin symbolisiin systeemeihin. Tämän takia tavat, joilla puhumme (diskurssit), eivät ole yhtenäisiä, vaan puheella on "sisäinen tarve" erehtyä [err] tiettyyn määrään asti. (Lacan 1988a, 264.) Toisin sanoen Lacanin mukaan kuuluessamme erilaisiin symbolisiin systeemeihin emme voi puhua virheettömästi tai yhtenäisesti. Systeemien välinen eripura siirtyy puheeseemme. Symbolinen järjestys puolestaan on jonkinlainen yleiskäsite kaikelle, mikä on sidottu käsitteisiin, ilmaisuihin ja niiden merkityksiin. Se on symboliset systeemit kattava järjestys, missä ilmaisut saavat merkityksensä.

Symbolinen järjestys saa asiat näyttämään universaaleilta. Kuitenkaan universumi, jonka symbolinen rakentaa, ei ole sama asia kuin maailma. Koska symbolinen rakentaa oman universuminsa, minkään symbolisen yleistyksen [universal] ei tarvitse kattaa koko maailmaa ollakseen universaali. (Lacan 1988b, 29-33.) Jokainen uusi symbolinen systeemi luo itsestään stabiilin ja ajattoman kuvan (ibid., 5). Toisin sanoen symbolinen systeemi rakentaa itselleen menneisyyden. Tähän menneisyyden rakentamiseen kuuluu myös yksilön historian menneisyydessä oleva myyttinen vaihe, josta Lacan käyttää nimitystä imaginaarinen järjestys tai lyhyemmin imaginaarinen (imaginaire).

Imaginaarinen sijoittuu lähinnä varhaislapsuuteen ja sen kokemuksiin - aikaan ennen kielen oppimista noin 18 kuukauden iässä. Kuitenkin imaginaarinen on myös osa arkipäiväämme, sillä se liittyy egoon. Ego saa alkunsa peilivaiheessa, joka Lacanin mukaan tapahtuu kuuden kuukauden iästä aina 18 kuukauden ikään saakka. Peilivaiheessa lapsen aiemmin fragmentaariseksi kokema ruumis näyttäytyy eheänä, hallittuna kokonaisuutena (Gestalt) hänen katsoessaan peiliin. Samastumalla tuohon kuvalliseen kokonaisuuteen lapsi kokee itsensä yhtenäisenä. Tämä samastumisprosessi on kuitenkin väärintunnistamista (méconnaissance), koska kuva on erillään kokijasta. Se on toinen. Tämä toinen ei ole sama kuin lapsi, sillä se on peilikuva, ts. käänteinen (inverted) suhteessa katsojaan. Samastuessaan tähän kuvaan lapsi ottaa sen egoideaalikseen. Tämä ensimmäinen samastuminen on kaikkien myöhempien samastumisten edellytys ja lähtökohta. Peilissä nähdyn idealisoidun kuvan merkitys on siinä, että vasta se asettaa lapsen sisäisen ja ulkoisen todellisuuden erilleen. (Lacan 1977a, 1-4.)

Peilivaihe ei rajoitu vain visuaaliseen kokemiseen, vaikka Lacan puhuukin siitä lähinnä katsomisen kautta. Vanhemmatkin voivat toimia peilinä, jossa lapsi kokee oman yhtenäisen kuvansa. Lacan on kuvannut peiliä myös ikkunana, jossa nähdään heijastus itsestä liukumassa yhteen sen läpi nähdyn toisen hahmon kanssa (1988a, 141). Lacanin mukaan "peilin idea pitäisi ymmärtää objektina, joka heijastaa ei vain näkyvää, vaan myös sitä, mitä lapsi kuulee, koskettaa ja tahtoo" (Lacanilta lainannut Rose 1982, 30). Guy Rosolato (1974) onkin tältä pohjalta luonut käsitteen akustinen peili. Hänen mukaansa ihmisäänen ominaisuuksiin kuuluu, että se voidaan lähettää ja vastaanottaa - ääntää ja 
kuulla - yhtä aikaa. Tätä tapahtumaa hän sanoo akustiseksi peiliksi. Lapselle akustinen peili jäsentää sitä, mikä on hänen sisällään tai ulkopuolellaan jo 3-8 viikon iässä. Rosolaton kuvaamaa vaihetta voitaisiin kutsua akustiseksi peilivaiheeksi. Akustinen peilivaihe tapahtuu siis varhemmin lapsen kehityksessä kuin lacanilainen peilivaihe. Aikuisiällä akustinen peili toimii kokemuksissa, joissa musiikin kokija samastuu musiikkiin. Kokija voi vaikkapa laulaa äänettömästi tutun melodian mukana. Kokijan kurkunpään lihakset pyrkivät tällöin muokkaamaan olematonta ilmapatsasta ilman, että hän itse on edes tietoinen tuosta lihastoiminnasta. (Rosolato 1974, 77-81.)

Lacanilainen ego on tulkintani mukaan instanssi, joka muodostuu ihmisten kuviin, ääniin ja kosketuksiin samastumisten avulla. Lacan sanookin, että ego koostuu samastumisten sarjoista. Nämä samastumiset subjekti liittää oman elämänsä tiettyihin historiallisiin hetkiin. (Lacan 1988b, 165.) Egolla on imaginaarinen funktio siinä määrin kuin se on itsen kokonaiseksi kokemista visuaalisen, akustisen tms. peilin avulla. Lacanin mukaan meillä täytyy olla olemassa egon narsistinen suhde toiseen ennen kuin meillä voi olla suhde objekteihin. Tämä on ensisijainen ehto sille, että maailma voitaisiin objektivoida - oli tuo objektivointi naiivia, spontaania tai tieteellistä. (Ibid., 94.) Tulkitsen tämän objektivoinnin tarkoittavan maailman havaitsemista erillisinä objekteina egon avulla. Kuitenkin nämä peilin avulla havaitut muodot (Gestalt) ovat vain transitorisia, hetkellisiä, jos niitä ei nimetä. Tämä nimeäminen tapahtuu symbolisen järjestyksen avulla. Kun symbolinen nimeää objektit, ne saavat pysyvyyden. Nimetyt objektit asettuvat erilaisiin suhteisiin toistensa kanssa. Nämä suhteet vastaavat kielellistä merkityksenantoa saussurelaisessa mielessä. Merkin identiteetti syntyy sen eroavuudesta toisista merkeistä ja samalla tuon merkin representoiman objektin poissaolosta (Hietala 1990a, 231). Nimetyt objektit ovatkin enää vain objektien representaatioita.

Symbolinen vertautuu lakiin siinä määrin kuin se asettaa ilmaisut (signifiers) ja niiden tarkoitteet (signifieds) tiettyihin suhteisiin toisiinsa nähden. Symbolisen järjestyksen maailma saa tietyn muodon ja järjestyksen, jossa osat suhteutuvat kokonaisuuteen. Usein tämä laki vertautuu Isään. Isä isolla kirjaimella ei ole fyysinen henkilö, vaan joku, joka toimii 'isällisessä' asemassa. Perusmerkityksessään Isä on kieltäjä. Hän kieltää lapsen Äitiä ${ }^{1}$ kohtaan tunteman insestisen halun. Tämän takia "Isän sana on laki"' . Kieltäminen on olennainen, että maailma pysyisi lainalaisena kokonaisuutena. Jotakin on siis poistettu kiellettynä meidän symbolisesta todellisuudestamme. Insestinen halu syntyy poiste-

${ }^{1}$ Isolla kirjaimella kirjoitettu Äitikään ei ole välttämättä todellinen äiti, vaan joku, joka toimii äidin asemassa.

${ }^{2}$ Vrt. Lacanin käsitteeseen Le nom/non du Père - Isän nimi/ ei - josta vapaasti suomentamani "Isän sana on laki". 
tun todellisuuden osan takia. Se, mikä on poistettu todellisuudestamme, on Lacanin reaalista $\left(\right.$ réel $\left.^{3}\right)$.

Lacanille reaalinen on sellaista, josta ei puutu mitään $(1982,113)$. Siksi sen voidaan sanoa olevan täydellistä. Reaalisessa ei ole eroa sisäisen ja ulkoisen välillä. Tämän takia siinä ei voida sanoa olevan mitään rikkoumaa (fissure) (Lacan 1988b, 97). Reaalinen on jotain, joka täysin vastustaa symbolisaatiota (Lacan 1988a, 66). Se ei suostu määriteltäväksi ja on olennaisesti mahdoton (Lacan 1977b, xli ja 22). Mitä Lacan oikein tarkoittaa näillä kuvauksilla? Reaalinen vain on. Se representoi sitä, mitä ei voida representoida viittaus-, määrittely- ja merkityssysteemien toisella puolella. Reaalista ei voida kuvata. Se vain on olemassa symbolisen systeemin ulkopuolella - se eks-istoi (ex-ists). (Botting 1994, 24.) Reaalinen on tavallaan se pohja, jolle symbolinen todellisuus syntyy. Voitaisiin siis ajatella, että reaalinen olisi täyteys tai ykseys, joka symbolisaation takia on jakaantunut rikkonaisiksi osiksi, subjekteiksi ja objekteiksi. Kuitenkaan tämä yksi ei Lacanin mukaan ole ontologisesti rikkonaisuutta edeltävä. Symbolinen systeemi rakentaa oman rikkonaisuutensa - ilmaisun ja tarkoitteen eron - takia täyteyden referentikseen. Täyteys voi olla joko imaginaarinen, peilin avulla saatu yhtenäisyys tai ennen peilivaihetta ollut osittainen yhtenäisyys ulkoisen ja sisäisen välillä tai reaalinen, äärimmäisiä nautinnon tai kauhun kokemuksia herättävä yhtenäisyys.

Ihminen on Lacanin mukaan puutteellinen. Ihmisen myyttisin puute on se, että hänestä on tullut elävä, seksuaalisesti lisääntyvä olio. Lacanin mukaan se, että ihmisolio on alistettu seksuaaliselle lisääntymiselle, on osoitus yksilön kuolevaisuudesta. Tullessaan eläväksi olioksi yksilö on menettänyt kuolemattomuuden. Kaikki ihmisten toimet tähtäävät tuon itsestä menetetyn osan takaisin saamiseen, kuolemattomuuden uudelleen löytämiseen. (Lacan 1977b, 205.) Tämän takia kaikki kokemukset, joissa yksilö hetkellisesti saavuttaa itsestään menettämänsä osan, ovat hetkellisiä kuolemattomuuden välähdyksiä. Samalla ne kuitenkin vertautuvat kuolemaan. Vasta kuolemassaan ihmisolio saavuttaa uudelleen täyteytensä. Tällöin hän menettää subjektien ja objektien väliset erot, sisäisen ja ulkoisen välisen eron. Jumalainen kuolemattomuus on reaalista, totaalista eriytymättömyyttä.

Reaalista sinänsä ei voida kokea. Kuitenkin sen läheisyys voidaan havaita ja tuntea monella eri tavalla. Lacanin mukaan reaalisen kohtaamisen hetkellä joudutaan eroon symbolisesta ja sen kielisysteemistä. Kieli ei enää toimi reaalisen läheisyydessä. Tämän takia myös symbolisen järjestyksen muodostama oleellisesti kielellinen subjektius eli mahdollisuus sanoa "Minä" katoaa. Samoin on mahdollista, että egon imaginaariset samastumiset eroavat toisistaan. Egoa voi-

${ }^{3}$ Réel voitaisiin kääntää myös sanalla todellinen, mutta tällöin aiheutuisi turhaa sekasotkua käsitteiden todellinen ja todellisuus välille. Kiitän Jukka Sihvosta käännösehdotuksesta. 
taisiinkin ajatella tältä kannalta pinona päällekkäisiä diakuvia, jotka yhteen sulautuneina muodostavat kokijan egon. Reaalisen läheisyydessä tämä pino levittyy erillisiksi kuviksi. Kenties voitaisiin puhua jopa oman elämän näkemisestä filminä silmien edessä silloin, kun koetaan kuoleman läheisyyttä.

Reaalisen läheisyyden kokemus on usein äärimmäisen nautinnon (jouissance) kokemus. Nautinto on Lacanilla lähinnä orgastista: jouissance juontaa ranskan verbistä jouir, jolla on nauttimisen lisäksi orgasmin saamisen konnotaatio. Orgasmin eufemismi ranskaksi on pieni kuolema (la petite mort). Nautinto on siten hetkellistä kuolemattomuuden saavuttamista. Koska kuolemattomuus on poistettu meidän todellisuudestamme, on se olemassa samalla tavoin kuin reaalinen. Näin nautinto on reaalisen kohtaamista. Milloin tuo kohtaaminen reaalisen kanssa sitten tapahtuu? Lacanin mukaan tietyissä tilanteissa subjekti kulkee subjektin ja maailman välillä olevan lasin (peilin) läpi. Tällöin kaikki subjektin ja maailman väliset erot katoavat. Itse asiassa tällöin katoaa myös subjekti ja ego, ja kokija kohtaa reaalisen. (Lacan 1988a, 177-178.) Musiikkikokemuksessa tämä voidaan nähdä tapahtuvan silloin, kun kokija ei enää hahmota mitään egonsa avulla. Kokijan äänetön laulu musiikin mukana jumiutuu hänen kurkkuunsa - hän ei voi enää laulaa mukana. Tällöin 'laulamisen' muodostama akustinen peili katoaa ja kokija kohtaa reaalisen. Tällaisia akustisia samastumisen rikkojia voivat olla hetket, jolloin musiikki lähestyy huutoa, esimerkiksi silloin kun melodia kohoaa sellaiseen rekisteriin, jossa kokija ei enää pysty 'laulamaan' mukana. Samoin oopperassa laulumelodiat usein hipovat huutoa tai jopa muuttuvat siksi.

\section{Musta aukko todellisuudessa}

Lacanin mukaan vieteillä on elimellinen perustansa. Vietit syntyvät silloin, kun jotain erotetaan omasta ruumiista elimenä. Tämä erotus tapahtuu siksi, että ihmisestä voisi kielen oppimisen myötä tulla subjekti (Lacan 1977b, 103). Ensimmäinen ja myyttisin erotus on ohut kalvo (lamella), joka irtautuu samalla, kun sikiö syntyy lapseksi. Tämä lamella on kuolematon tai jopa itse kuolemattomuus. Se on Lacanin mukaan libido, seksuaalivietti siinä määrin kuin se on puhdas elämän vaisto. Lamella on elävän subjektin ja kuolemattomuuden välinen suhde. Muita itsestä objekteiksi erotettuja osia Lacan kutsuu nimellä objets petit $a$. Ne ovat objekteja, joilla on vain vähän (petit) toiseutta ( $a$ - sanasta autre $=$ toinen). Niiden synty sijoitetaan aikaan ennen peilivaihetta, jolloin sisäisen ja ulkoisen maailman rajat olivat vielä epämääräiset. Tällöin esimerkiksi äidin rinta ja ääni vielä kuuluivat lapselle, mutta olivat kuitenkin erillään siitä. Menetetyt objektit ovat tarpeellisia, jotta kadotettu täyteys voitaisiin saada takaisin. Objets petit a synnyttävät siten vietit, jotka pyrkivät kohti menetettyjä objekteja. (Ibid., 195-199.) 
Objet $a$ on menetyksen synnyttämä objekti, joka saa arvonsa kokonaisuudesta erottamisensa ansiosta. Lacanin mukaan todellisuus on riippuvainen objet $a: n$ poistamisesta. Kuitenkin tämä objekti rajaa todellisuuden. (Lacanilta lainannut Žižek 1991, 94.) Jacques-Alain Millerin mukaan todellisuuden pysyvyys riippuu juuri objektin poistamisesta. Kun kuvasta poistetaan pala, palan reunat rajaavat kuvaan tyhjän aukon. Samalla tyhjyyden reunat rajaavat koko kuvapinnan. Tyhjä aukko on todellisuuden rajaava objet a. (Milleriltä lainannut Žižek 1991, 94-95.) Tätä kautta tulee myös selväksi objet a:n ja reaalisen suhde: Objet a poistetaan symbolisesta todellisuudesta samalla tavoin kuin reaalinen. Objet $a$ :n saavuttamiseen liittyvissä kokemuksissa on mukana reaalisen läsnäolo.

Objets $a$ ovat niitä objekteja, joiden ympäri vietit kiertävät. Tämä $a$ on reikä - sitä voi kutsua jopa mustaksi aukoksi - tai tyhjiö, jonka voi täyttää mikä tahansa menetetty objekti. Vietin objektilla on se merkitys, että se takaa vietin reitille yhtenäisyyden, ts. että viettienergia lähtee ja palaa takaisin kaartaen objektin ympäri. (Ibid., 180-181.) Vietin kaarrosta Lacan kuvaa seuraavalla kaaviolla (Muotoillen lainattu Lacan 1977b, 178):

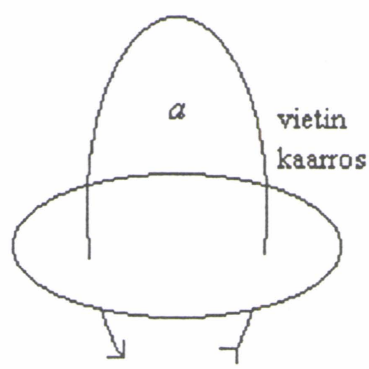

Kaikki vietit pyrkivät saavuttamaan objet $a$ :n representoiman kuolemattomuuden, joka saataisiin yhteydestä objet $a$ :n kanssa. Kuitenkin objet $a$ on se, joka pitää todellisuutta yllä. Jos siis yhteys siihen saadaan, tarkoittaa se todellisuuden katoamista. Tämän takia Lacan sanookin, että objet $a$ on se, jonka edessä subjektius romahtaa (ibid., 258).

Vietti toimii loputtomana kiertävänä liikkeenä tavoittelemansa objektin ympäri, mikä aiheuttaa nautintoa (jouissance) epäonnistuneessa saavuttamisessa. Kuten Slavoj Žižek sanoo, vietin tila on kaareutunut tila. Hänen mukaansa vietti ei ole lopulta muuta kuin tilan kaareuma itse, joka aiheuttaa sen, että meidän täytyy kurvata juuri silloin, kun haluamme päästä käsiksi objektiin. (Žižek 1992, 48-49.) Analogian avulla pääsemme käsiksi vietin kaarroksen aikaan ja 
tilaan. Objet petit a:ta voidaan verrata mustaan aukkoon ${ }^{4}$, tai tarkemmin se on tapahtumahorisontin rajaama alue.

Hawkingin mukaan painovoima heikkenee edettäessä mustasta aukosta kauemmaksi. Jos uskalias astronautti pyrkisi laskeutumaan mustaan aukkoon, painovoiman ero "venyttäisi astronautin kuin spagetin ja repisi hänet palasiksi" ennen kuin hän törmäisi singulariteettiin. (Hawking 1988, 88.) Tämä kuvaa mielestäni hyvin tilannetta, jossa subjekti tulee liian lähelle reaalista tai objet $a$ :ta. Reaalisen "painovoima" tuhoaa subjektin ja venyttää egon diakuvapinon nauhaksi yksittäisiä ruutuja. Jos subjekti törmää reaaliseen singulariteettiin, hän kuolee. Kuitenkin on Hawkingin mukaan mahdollista, että singulariteettiin törmääminen vältettäisiin. Tällöin astronautti pujahtaisi "madonreiän" kautta toiseen, menneeseen aika-avaruuteen. (Ibid., 89.) Tämä johtuu siitä, että mustan aukon läheisyydessä aika hidastuu.

Samoin voidaan nähdä tapahtuvan lähestyttäessä objet $a$ :ta. Vietin syöksyessä objektinsa painovoimakenttään se lähenee reaalisen ajattomuutta. Tällöin kokemuksellinen aika hidastuu. Kokija tavallaan siirtyy reaalisen läheisyydessä menneisyyteen. Vietin pujahtaessa madonreiän kautta menneeseen voidaan tilan kokea laajenevan, koska nähdään kahteen ulottuvuuteen - nykyisyyteen ja menneeseen. Toisaalta ajan lähestyessä reaalisen ajattomuutta tilan kokemus samalla lähenee tilattomuutta, joka käänteisesti voidaan kokea äärettömänä tilana. Nämä kokemukset ovat mielestäni kuvaavia, kun kysymyksessä on nautinnollinen kokemus.

${ }^{4}$ Stephen Hawkingin mukaan musta aukko on aika-avaruuden singulariteetti. Singulariteetti on alue, jonka pinta-ala ja tilavuus ovat nolla. Tällöin aineen tiheys ja aika-avaruuden kaareutuminen ovat äärettömiä. (Hawking 1988, 51.) Samalla tavalla reaalisella ei ole tilaa, vaan se on tilan ääretön kaareuma. Objet $a$ taas on tilan kaareuma, mutta ei ärärön.

Mustat aukot ovat painovoimaltaan niin suuria, että ne estävät valon pääsyn pois pinnaltaan. Mustan aukon ulkoreunaa kutsutaan tapahtumahorisontiksi. Se on raja, jolta valo on juuri pääsemäisillään ulos. (Ibid., 82 ja 86.) Musta aukko on tapahtumahorisonttinsa kanssa tavallaan niin kuin omena, jossa siemenkota vastaa singulariteettia ja tapahtumahorisontti omenan pintaa:

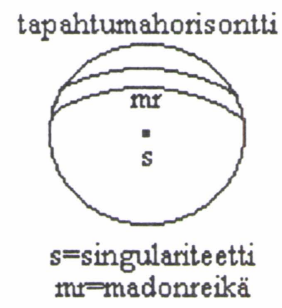


Elokuvassa tilan ja ajan vääristyminen voidaan nähdä Žižekin kuvaamassa hitchcockilaisessa tracking shotissa. Objet a:ta ei saavuteta vauhdin takia. Sitä ei voida kuvata (lähestyä) kuin liian hitaasti tai liian nopeasti, koska normaalinopeudella objekti ei ole mitään. Se on tyhjä. Objekti saavutetaan vain hitaasti tai nopeasti. (Žižek 1991, 94.) Toisaalta mustaa aukkoa ei Hawkingin mukaan voida havaita suoraan, koska niitä ei voida nähdä. Ne voidaan havaita vain niiden painovoiman kautta. (Hawking 1988, 94-95.) Samalla tavalla elokuvasta voidaan usein havaita objet a:n läheisyys sen vaikutuksesta ympäristöön. Objet a hidastaa (tai nopeuttaa) kuvaa. Tutkimalla hidastuskuvia voidaan monissa tapauksissa varmistua objet a:n läheisyydestä.

Lacanin mukaan objet $a$ on joko esisubjektiivista tai se on samastumisen perusta $(1977 b, 186)$. Tätä kautta on mielestäni nähtävissä se, että samastumalla tiettyyn objektiin peilivaiheen kaltaisesti, on tuosta objektista mahdollista tulla objet $a$. Tämä tapahtuu silloin, kun tuota objektia ei nimetä, vaan se on olemassa vain hetkellisesti. Kun yksilö akustisen peilin avulla samastuu musiikkikokemuksessa esimerkiksi johonkin teemaan, on mahdollista, että teemasta tulee menetetty objekti. Teemaa ei nimetä, vaan se koetaan hetkellisesti. Kun teema toistetaan, päästään uudelleen sen lähelle ja tästä täyteyden saavuttamisesta saadaan nautintoa. Tällainen kokemus ilmenee mielestäni Jane Campionin elokuvassa Piano. Musiikkikokemuksessa voi mielestäni myös tapahtua egon eriytyminen eri samastumisiksi. Tilanne vastaisi diakuvapinon erottautumista yksittäisiksi kuviksi mustaan aukkoon vertautuvan objet $a$ :n läheisyydessä. Kokijan 'äänellinen ego' kuuluisi samaan aikaan yhdessä aika-avaruudessa. Tällainen tilanne voisi olla kyseessä esimerkiksi Wagnerin Götterdämmerungin loppu, jossa useat eri aiemmissa Ring-tetralogian oopperoissa kuullut johtoaiheet soivat päällekkäin.

\section{Adan ääni}

Žižekin mukaan ihminen on pakotettu valitsemaan "Isän tai huonomman" välillä. Tämä tarkoittaa sitä, että meidät on pakotettu valitsemaan yhteisöllinen, symbolinen (ts. Isä). Valinta on samalla menetys. Subjekti menettää "insestisen" objektin, joka on mahdottoman nautinnon kiteytymä. Symbolinen järjestys, joka rakentaa subjektin, pakottaa subjektin valitsemaan yhteisöllisen. Yksilön mahdollisuus valintaan on harhaa, koska symbolinen antaa sen vasta sen jälkeen, kun tuo valinta on jo tehty. Jos subjekti kuitenkin valitsee yhteisöllisen toiseuden, nautinnon, hän valitsee psykoosin. Tässä huonommassa valinnassa tuo nautinto on objet petit a. (Žižek 1992, 74-75.) Toisin sanoen lacanilainen nautinto on symbolisen vastaista, koska se liittyy objet $a$ :han, joka on todellisuudesta poistettu osa.

Piano-elokuvan päähenkilö Ada on kieltäytynyt valitsemasta symbolista. Hän on luopunut puhumisesta, joka olisi symbolisen järjestyksen alaista. Hä- 
nen puhumattomuutensa ilmentää tulkintani mukaan valintaa äänellisen nautinnon hyväksi. Kuitenkaan Ada ei ole psykoottinen. Hän on hyvinkin integroitunut symboliseen esimerkiksi viittomien ja pienten kirjelappujen avulla. Hän on siis pystynyt tekemään valinnan, jonka avulla hän voi kuulua yhteisöön nautinnostaan luopumatta. Valintaa nautinnon hyväksi korostaa elokuvan ehkä vaikuttavin kohtaus, jossa Adan puoliso Alistair Stewart hakkaa kirveellä Adan sormen irti. Tässäkin tilanteessa Ada kieltäytyy ilmaisemasta itseään äänellisesti. Žižekille huuto on vapautus sietämättömästä jännitteestä - se on päätös ja valinta. Jos taas huuto tukahtuu, osoittaa se objet a:n läheisyyden. Hänen mukaansa tukahtunut huuto on "kurkkuun takertunut luu", objet petit a. (Ibid., 117-118.) Äärimmäiselläkään hetkellä Ada ei suostu päästämään huutoa, johon Alistair hänet yrittää pakottaa. Ada siis kieltäytyy menettämästä nautinnon tuojaansa, objet a:ta.

Tätä kieltäymystä elokuva korostaa Adan tyttären, Floran avulla. Ennen Alistairin tapaamista Flora sanoo Adalle, että ei tule kutsumaan miestä isäkseen. Kun asiat alkavat mennä avioliiton kannalta huonommin, ts. kun Ada alkaa saada nautintoa symbolisen järjestyksen alaisuuteen lukeutuvan avioliiton ulkopuolelta suhteestaan George Bainesin kanssa, Flora alkaa kutsua Alistairia isäkseen [Papa]. Näin Flora osoittaa tehneensä valinnan symbolisen hyväksi. Valintaa osoittaa myös Adan sormen katkaisukohdassa Floran kauhunhuuto: "She says NOoo!... Mother!" vastauksena Alistairin kysymykseen Adalta: "'Do you love him?". Koska Ada ei viito käsillään mitään, on tyttären vastaus väärä. Flora yrittää vain suojella äitiään.

Kohtaus on tyttärelle traumaattinen reaalisen kohtaaminen. Annettuaan Georgelle Alistairin lähettämän irtihakatun sormen Adan tarkoittaman pianonkoskettimen sijaan, hän ei pysty muuta kuin ulvomaan ja toistamaan lauseita, joissa kaikuu Alistairin uhkaus katkoa lisää Adan sormia. Floran ulvontaa voidaan verrata Fred Bottingin $(1994,38)$ kuvaamaan tapaan reagoida reaalisen ilmestymiseen. Hänen mukaansa kokija voi vastata reaalisen läheisyyden kokemukseen loputtomalla puheella, joka ei voi muuta kuin toistaa reaalisen näyttäytymisen aiheuttamaa kauhua. Toinen vaihtoehto reagoida reaalisen purkautumiseen on hänen mukaansa hiljaisuus, johon subjekti katoaa. Floran äänekäs reaktio on vastaus reaaliselle hiljaisuudelle, kun taas elokuvan katsoja ei voi muuta kuin olla kauhusta hiljaa.

Elokuvassa kuitenkin kuullaan Adan ääni. Tämä ei ole hänen puheäänensä, vaan kuten hän sanoo, "mieleni ääni"'. Alussa Ada kertoo, ettei ole puhunut sen jälkeen, kun oli kuusivuotias. Myöhemmin käy ilmi, että hän on aloittanut pianonsoiton samoihin aikoihin. Hän kieltäytyy yhteisöllisestä puheesta pianonsoitosta saatavan nautinnon hyväksi. Tätä valintaa hän ei kuitenkaan tiedä tehneensä, koska elokuvan alussa hän sanoo, ettei tiedä, miksi lopetti puhumisen. Sisäinen puhe saa mielenkiintoisia piirteitä elokuvan aikana. Alun puhe lukeutuu konventioihin, joissa joku selittää elokuvan tapahtumien syitä. Kun käy ilmi, että vain kolme henkilöä on kuullut Adan mielen äänen (pianonsoi- 
tonopettaja, George ja Alistair), muuttuu myös elokuvan lopussa kuultavan puheen merkitys. Milloin nuo kolme henkilöä, joista yhtä ei esiinny elokuvassa kuin kertomuksen muodossa, kuulevat Adan sisäisen äänen? Mahdollisesti silloin, kun Ada on heihin jonkinlaisessa seksuaalisessa suhteessa.

Kun George ja Ada ovat rakastelleet, George kysyy: "What? Whisper it." Mielestäni tämä on hetki, jolloin George kuulee Adan sisäisen äänen, vaikka hän myöhemmin kieltääkin Alistairille koskaan kuulleensa "Words? No, not words". Vastaus on ambivalentti, koska George saattaa antaa toisen nimen tälle sisäiselle puheelle. Toisessa tapauksessa Adan puheen kuulija on Alistair. Tämä tapahtuu sormenleikkuun jälkeen, kun Ada on vuoteenomana ja Alistair yrittää rakastella hänen kanssaan. Kolmannessakin tapauksessa on kyse Adan seksuaalisesta suhteesta mieheen. Mitä ilmeisimmin hän oli rakastellut myös pianonsoitonopettajansa kanssa, koska Ada oli saanut tyttären, Floran. Tämä mies oli kuitenkin pelästynyt Adan ääntä ja jättänyt hänet. Alistairillekin tämä sisäinen ääni on outo, sillä hän haluaa päästä eroon Adasta, "I wish her gone". Vain George ymmärtää Adan äänen, hyväksyy sen ja nauttii siitä.

Miten Ada sitten pääsi tähän yhteyteen miesten kanssa ja mikä on seksuaalisuuden suhde siihen? Ada teki näille miehille jotakin samaa kuin pianolleen. Elokuvassa paljon kuvattujen käsiensä avulla Ada saa herätettyä pianosta musiikkia, joka toimii hänelle akustisena peilinä. Hän siis saa kuulla omaa ääntään toisessa. Soittaessaan hän kuulee käsiensä herättämän äänen, joka on hänen oma äänensä. Samalla tavalla hyväillessään miehiä, rakentaessaan käsillään peilin itsensä ja toisen (miesten) välille hän saa oman äänensä kuuluviin. Tämä selittää sen, miksi Ada, Alistairin lukittua heidät talon sisälle, alkaa hyväillä miestään öisin. Kyseessä ei ole seksin puute, kun Ada ei pääse Georgen luo. Hänen on pakko yrittää rakentaa peili itsensä ja Alistairen välille, jotta voisi puhua hänelle suoraan. Tältä kannalta katsottuna piano ja sen musiikki toimivat Adalle rakastajana/rakastettuna. Suzanne Cusickin (1994, 73-79) mukaan vuorottelemalla sillä, kuka tuottaa mielihyvää toiselle ja kuka saa vallan, voidaan määritellä rakastaja/rakastettu-suhde. Jos seksi on vallan ja läheisyyden sovittelemista mielihyvän kierrättämisen (antamisen ja saamisen) avulla, niin mikä estää musiikkia olemasta seksiä, Cusick kysyy. Tämän takia on ymmärrettävää, miksi Ada haluaa päästä eroon pianosta lopun merimatkalla. Tietäessään, että George pystyy kuulemaan hänen sisäisen äänensä sen avulla, mitä hän (Ada) Georgelle käsillään tekee, hän voi luopua tuosta entisestä (kenties kuitenkin enemmän) rakastetustaan (kuin rakastajasta). Hän tietää, että George voi olla hänen rakastettunsa, mutta myös sen, että George voi olla antava osapuoli, rakastaja. Syntyy valtasuhteen tasapaino, jossa parisuhteen kumpikaan osapuoli ei perinteisen mies-aktiivinen, nainen-passiivinen -roolijaon mukaan ota tiettyä kiinteää positiota, vaan valta kiertää toiselta toiselle.

Mitä Adan puheääni elokuvan lopussa sitten merkitsee kokijalle? Jos elokuvan kokeminen muistuttaa peilivaihetta tai ainakin saa aikaan meissä samantapaisia tuntemuksia kuten Christian Metz $(1990,101-108)$ on kuvannut, niin 
eikö tällöin Adan puheen tulisi olla osoitus ruumiillisesta suhteestamme elokuvan ruumiiseen? Onko elokuva siis soittanut ja hyväillyt meidän ruumistamme? Asettuuko elokuva siten asemaan, jossa meille on annettu valta? En pysty vastaamaan näihin kysymyksiin. Kenties Adan puhe nousee elokuvan ansiosta jostain meidän sisältämme, kenties me olemme sillä hetkellä Ada, kun hän alkaa puhua kuoleman (reaalisen) kohtaamisen jälkeen, kenties me sanoisimme samassa tilanteessa saman:

"What a death.
What a chance.
What a surprise.
My will has chosen life
It's to tell, it has had me spooked and many others besides."

\section{Pianon ääni}

Elokuvassa on yhtenä merkittävänä äänenä käytetty pianon tuottamaa sointia, kun siihen isketään jollain esineellä. Isku tuottaa diffuusin sointimaton, koska se saa pianon kaikki kielet värähtelemään. Sointimatto ei elokuvassa ole aina sidoksissa itse instrumenttiin. Sitä voidaankin kutsua chionilaiseksi akusmaattiseksi ääneksi. Žižekin (1991, 126-127) käsittelemän Chionin mukaan akusmaattisella äänellä ei ole selvää kantajaa. Sitä ei voida kunnolla paikallistaa diegeesikseen eikä epädiegeettiseen ääniraitaan. Ääni ikään kuin väreilee näiden kahden tilan välimaastossa. Tällainen ääni aiheuttaa kokijassa jännitteen, joka purkautuu helpotuksen tunteeseen - jopa poeettiseen kauneuteen - kun ääni vihdoin löytää kantajansa eli kun sille löytyy lähde. Ennen tätä "deakusmatisaatiota" ääni on uhka. Sen vapaana lipuva läsnäolo on sama kuin epäsubjektivoidun objektin läsnäolo. Kun ääni vihdoin liitetään sen synnyttäneeseen objektiin, tuo ääni tulee subjektivoiduksi.

Pianon synnyttämää sointimattoa käytetään elokuvassa useissa eri kohdin. Ensimmäisen kerran se esiintyy maorien tutkiessa tavaroita, kun Alistair saapuu heidän kanssaan rannalle ottamaan Adaa ja Floraa vastaan. Seuraavan kerran piano soi, kun sitä kannetaan Georgelle ja se tipahtaa. Nämä kohtaukset tosin antavat selvän kuvan siitä, että piano on soinnin lähde, mutta kenties syynä onkin diegeettinen pakko. Pianon tulee soida, kun sitä isketään tai kun se iskeytyy johonkin. Toisaalta näissä tapauksissa kuuluu myös selkeä iskun ääni, joka myöhemmässä akusmatisoitumisen vaiheessa on poistettu.

Kun pianon kumina esiintyy seuraavan kerran, alkaa se saada uhkaavia piirteitä. Samalla kumahdukseen (sointimattoon) liittyvä alkuisku on heikompi kuin aiemmin. George sulkee pianon kannen kohtauksessa, jossa hän on pyytänyt Adaa makaamaan vieressään viittä mustaa kosketinta vastaan. Ada ja George ovat aiemmin tehneet sopimuksen, jonka mukaan Ada saa pianon itsel- 
leen sen jälkeen, kun on vieraillut Georgen luona niin monta kertaa kuin pianossa on mustia koskettimia. Ada ei tahdo pysyä Georgen vieressä, vaan nousee sängyltä ja menee hyväilemään pianoa ikään kuin lepyttelemään sitä siitä, että oli pettänyt rakastajaansa/rakastettuaan jonkun muun kanssa. Georgen sulkiessa pianon kannen Ada näyttää pettyneeltä tästä "väkivallan" osoituksesta Georgen puolelta. Toisaalta pettymys voidaan nähdä myös pettymisenä Georgen kyvyttömyyteen tajuta Adassa heräävää luottamusta häntä kohtaan.

Tämän jälkeen sointimatto akusmatisoituu täysin, sillä se siirtyy Alistairin yhteyteen. Samalla alkuisku poistuu kokonaan. Ensimmäisen kerran Alistair kantaa tätä ääntä, kun hän näkee omin silmin Adan ja Georgen hyväilyt talon seinässä olevan reiän läpi. Seuraavan kerran se vilahtaa taustaäänissä, kun Ada ensimmäisen kerran alkaa hyväillä Alistairea talon lautavuorauksen jälkeen. Sitten se esiintyy kohtauksessa, jossa Ada toisen kerran hyväilee Alistairea. Vaikka näyttää siltä, että sointimatto liittyy Adan hyväilyihin $(1 \times$ George, $2 \mathrm{x}$ Alistair), niin seuraava sointimaton esiintymiskerta kumoaa tämän väittämän. Sointimatto kuuluu, kun Alistair on ottanut laudat pois ikkunoista ja istuu Adan vieressä sängyllä sanoen 'I've decided to trust you'.

Ääni ei deakusmatisoidu, vaikka se seuraavan kerran ilmeneekin juuri ennen sormenleikkuuta kohdassa, jossa Alistair iskee kirveen pianoon. Tällöin nimittäin koko kohtausta dominoivat hidastetut kuvat ja kirveeniskun aiheuttaman soinnin kaiutus. Akusmaattinen sointimatto tuntuukin kuvaavan Alistairen väkivaltaisuuden aiheuttamaa uhkaa. Kaiutettu pianon sointimatto soi myös kohtauksessa, jossa Alistair lähentelee tajutonta Adaa. Tämä ääni tuo uhkaavuutta kohtaukseen, jossa Alistair menee yöllä Georgen luo. Ääni hivutetaan sisään samalla, kun Alistair astuu Georgen talon sisälle. Sen voimakkuus kasvaa, kun hän osoittaa Georgea aseellaan.

Kuitenkin sointimatto saa kaiken tehonsa vasta, kun piano heitetään mereen Adan pyynnöstä. Tällöin veteen iskeytymisen ääni on hyvin pehmeä, joten se ei merkitse muuta kuin diegeettisen todellisuuden mukaisuutta. Sen sijaan sointimatto kuuluu kaikkein eniten kaiutettuna. Sointi poistuu siksi hetkeksi, kun kuvataan jalkansa köysivyyhteen laittavaa Adaa. Samantapainen kaiutettu sointi kuuluu myös Adan iskeytyessä veteen. Hetkeen ei kuulu voimakasta sointimaton ääntä, mutta kun kamera siirtyy kuvaamaan pianoa ja liukuu siitä Adan köytettyyn jalkaan, tulee sointimatto jälleen etualalle. Näin sointimatto liittyy pianon lisäksi myös sen painoon ja Adan kuolemaa hipovaan kokemukseen. Kun piano nähdään meren syleilyssä, kuullaan viimeisen kerran tuota sointia. Ääni liittyy pianoon, mutta tämä vaikutussuhde ei ole mielestäni mitenkään selkeä.

Sointimatto liittyy kohtiin, joissa Ada on läheisessä suhteessa jompaan kumpaan mieheen tai joissa tämä ääni enteilee kohtalokkaita tekoja. Jälkimmäisiin tapauksiin luen sointimaton uhkaavuuden liittyen Alistairin aseisiin (kirves, pyssy), joilla hän voi tappaa. Myös Adan kohtaama kuoleman läheisyys meren syvyydessä "soi". Ensimmäisetkin tapaukset liittyvät kuolemaan nautinnon 
kautta. Ranskalainen eufemismi orgasmille on pieni kuolema (la petite mort). Näin kaikki, mikä liittyy ruumiilliseen - ja itse asiassa muuhunkin - nautintoon (jouissance), liittyy myös kuolemaan ja sen kokemiseen. Kenties ääni voidaankin siten liittää tiedostamattomaan.

Lacanin mukaan se, mikä reaalisen kohtaamisessa tulee esiin subjektin häviämisen jälkeen, on tiedostamaton subjekti (1988a, 178). Tiedostamaton on paikka, jossa vietit ja halu jylläävät. Tätä kautta päästään käsiksi siihen, kuinka reaalisen kohtaaminen liittyy tiedostamattomaan. Meitä ohjaavat vietit ajavat meidät kohti nautintoa, joka elokuvassa ilmenee tässä yhteydessä ruumiillisena. Aggressio taas liittyy imaginaariseen suhteeseen (Lacan 1988b, 177). Imaginaarisessa suhteessa toinen aiheuttaa subjektille puutteen - toinen on erillään subjektista. Kun Ada on synnyttänyt imaginaarisen suhteen itsensä ja Alistairen välille, Alistairen pelko menettää Ada muuttuu aggressioksi. Halu toista kohtaan näyttelee siis tässäkin tiedostamattomasta purskahtavaa voimaa. Adan hyppy meren syleilyyn ei kuitenkaan ole muuta kuin kuoleman vietin puhtain ilmenemä tässä elokuvassa.

Kun elokuva subjektivoi (deakusmatisoi) sointimaton, liitetään sointi tiedostamattomaan. Pianon "sointi" meren sylissä on tiedostamattoman subjektin puhetta. Kuitenkin tuo puhe on meille lalangueta, kielen ylijäämää (Ihanus 1995, 104), joka ei enää merkitse mitään muuta kuin, että tiedostamaton subjekti ilmaisee läsnäolonsa. Mikä on sitten sen yhteys pianoon? Lacanille tiedostamaton on Toisen diskurssia (Ks. esim. Lacan 1988b, 85). Tiedostamaton on jotain, joka on tullut subjektiin tämän ulkopuolelta, symbolisesta. Tiedostamaton on subjektin sisällä, mutta se voidaan havaita (realised) vain subjektin ulkopuolella, Toiseudessa (Lacan 1977b, 147). Piano on siis tiedostamaton, joka puhuu läpi elokuvan lalanguellaan. Koska subjektivoitu sointimatto liitetään näinkin abstraktiin asiaan kuin tiedostamattoman puhe, ei tuo deakusmaatio tuo suurta helpotuksen tunnetta. Sen sijaan elokuvan loppu on hyvinkin poeettisen kaunis, mitä tietenkin korostaa Adan sisäisen puheen runollisuus. Adalle pianon lalangue on kehtolaulua, joka tuudittaa hänet uneen.

\section{Musiikista, ajasta ja tilasta}

Pianossa on oikeastaan kaksi musiikillista teemaa, jotka dominoivat. Toinen näistä on teema, joka on useimmin soitettu pianolla ja toisinaan soinnutettu jousilla. Teeman ensimmäinen esiintymä on ensimmäinen kohtaus rannalla, johon merimiehet ovat Adan ja Floran jättäneet. Kutsun tätä teemaa pääteemaksi. Toinen teema liittyy useimmiten Floraan ja se onkin lastenlaulun omainen. Sen sanoista olen ymmärtänyt vain, että siinä lauletaan pojista ja tytöistä. Tätä teemaa kutsun siten nimellä "Lads \& Lassies". 

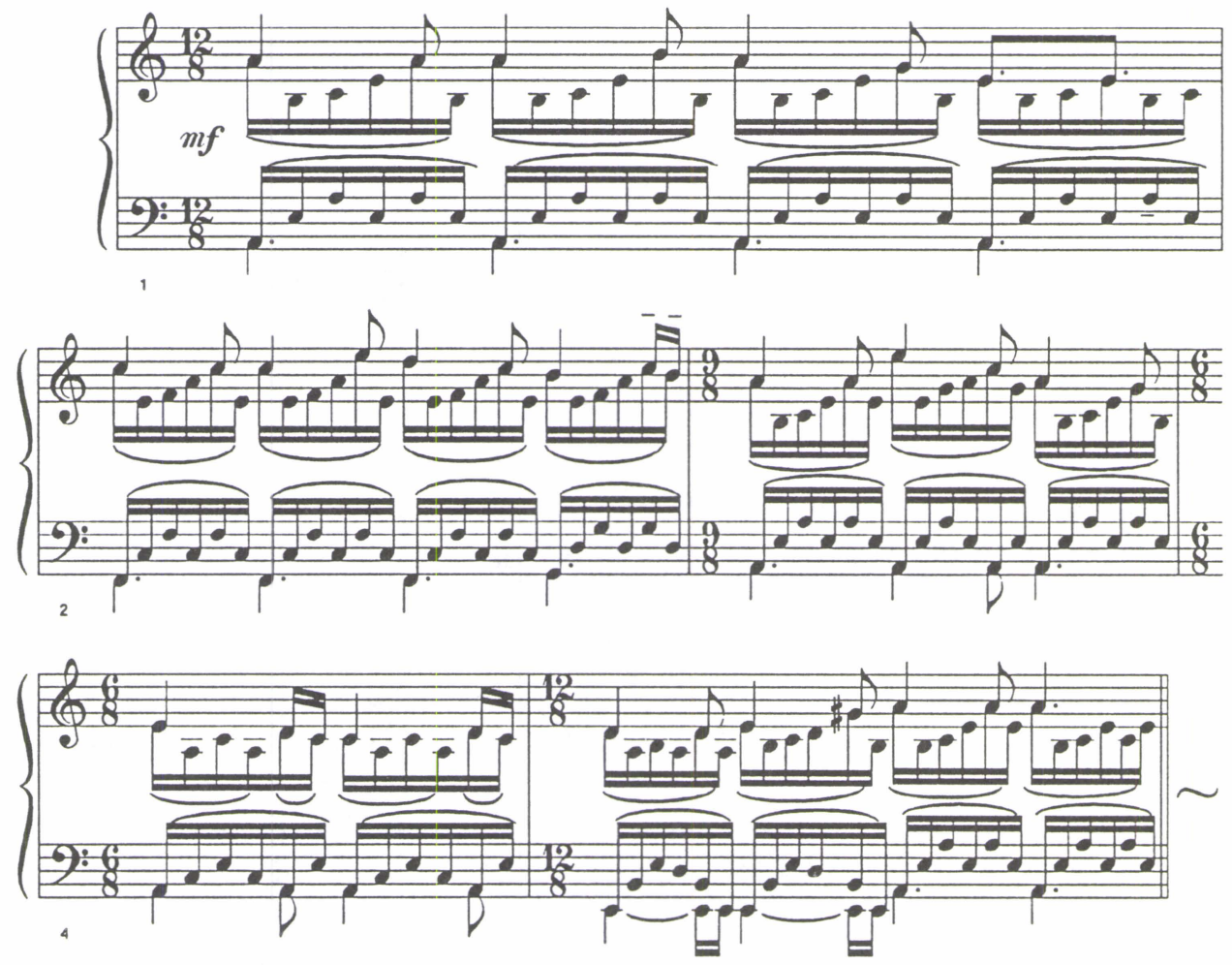

Pääteema
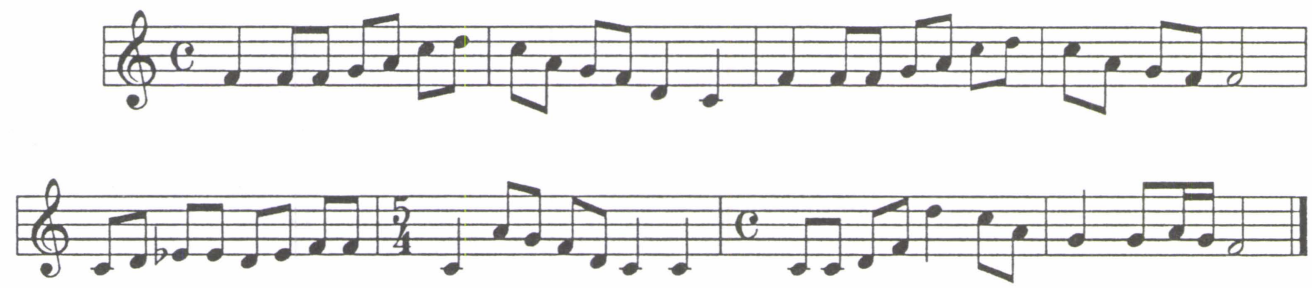

Lads \& Lassies

Sävelien ja sävellajien nimet nivoutuvat symbolisesti elokuvan sisältöön. Pääteema on kirjoitettu a-molliin. Toinen Adan soittama teema, joka on vielä lyyrisempi ja 1800-luvun romantiikkaa imitoiva, on kirjoitettu $\mathrm{D}$-duuriin. Ada soittaa sitä alkusekvenssissä ennen matkaa. Teemojen sävellajien nimistä saadaan tulokseksi: Ada. A-niminen on myös sävel, jota vastaavan pianonkoskettimen Ada yrittää lähettää Georgelle. Georgen ensimmäisellä pianotunnilla Ada soinnuttaa C-duuriasteikon a-molliin (vaihdellen As-duurin kanssa). 
Muistellessaan pianonsoitonopettajaansa ja heidän välistä rakkauttaan Ada koskettaa (nostaa) kosketinta, joka on ilmeisesti H (tai sitten E). Videolta en pystynyt näkemään, mikä oli Adan tuohon koskettimeen kirjoittama kirjain. Oletan, että se on H. Floran teema "Lads \& Lassies" on kirjoitettu F-duuriin. Aivan elokuvan lopussa, kun Ada on jo Georgen ja Floran kanssa Nelsonissa, Ada hellii metallisormellaan kosketinta G. Luen tämän viittaavan Georgeen. Kun hän tällöin alkaa soittaa "Lads \& Lassies" -teemaan on se G-duurissa.

Mikä sitten on näitten teemojen merkitys? Pääteema saa ensimmäisen merkityksen, kun Alistair ei suostu kuljettamaan pianoa talolleen. Ada katsoo ylhäältä rantakalliolta alas rannalle jääneeseen pianoon samalla, kun pääteema esiintyy ensimmäisen kerran kokonaisuudessaan (teeman alku kuultiin juuri rannalle saapumisen jälkeen). Mielestäni tässä kohtaa elokuva rakentaa teemasta objet a:n, menetetyn nautinnon lähteen. Teeman alku rannalla kuvaa vielä Adan täyteyden tilaa, mutta pianosta eroon joutuminen nostaa teeman objektin asemaan, jolloin sen tavoittelusta tulee nautinnon lähde. Tämä on mielestäni selitys sille, miksi tämä kohtaus on niin vaikuttava. Alistairiin kiteytynyt symbolinen Isän järjestys vieroittaa meidät (Adan) omasta äänestämme. Oman äänen menetyksen tunnetta lisää hetkiä myöhemmin kuvat Adasta, joka on repinyt hääpuvun yltään ja joka katsoo ulos myrskyyn, sekä kuva pianosta yksin rannalla pääteeman duuriosan soidessa hidastettuna versiona.

Seuraavan kerran pääteeman soidessa on se jo objekti, jonka läheisyydestä saadaan nautintoa. Teema alkaa soida, kun Ada ja Flora ovat pyytäneet Georgea viemään heidät rannalle. Musiikin siivittämänä pääsemmekin sinne. Tämä on kohtaus, jossa Ada nauttii teeman soittamisesta. Samalla kuitenkin elokuva alkaa vihjailla, että Adan ja Georgen välillä voi olla jotain - että Georgesta on tulossa Adan nautinnon lähde. Kuva siirtyy Adasta Georgeen, kun teeman duuriosa tulee kuuluviin, kuva siirtyy Adasta Georgeen. Musiikin soidessa kamera kuvaa vuorotellen Adan nautinnollisia kasvoja ja Georgea, joka katselee häntä.

Tätä siirtymää nautinnon kohteesta toiseen vahvistaa seuraava pääteeman esiintymä. Siinä Ada soittaa Georgelle, joka hyväilee Adan takkia. Ada ojentelee niskaansa nautinnollisesti, mutta lopulta lopettaa soittamisen ja ojentaa kätensä takkia varten. Kirjoitin samasta kohtauksesta jo aiemmin: George haluaa maata vierekkäin viittä kosketinta vastaan. Ada kuitenkin nousee pian ja menee hyväilemään pianoaan aivan kuin ei osaisi vielä suhtautua Georgelta kenties saatavaan nautintoon. Toisaalta Adan osoittama pettymys voidaan nähdä osoituksena Georgen kiihkeyden aiheuttamasta turhautumisesta - Georgen on vaikea ymmärtää, että Adan on vaikeaa siirtyä yhdestä nautinnon tuottajasta toiseen.

Pääteema saa yhä enemmän kielletyn hedelmän makua, kun Alistair yrittää ottaa Adan väkisin metsässä nähtyään Adan ja Georgen rakastelevan. Adasta on tullut Alistairille saavuttamaton - mahdottoman nautinnon lähde, objet $a$. Teema soi nopeana versiona korkealle soitinnetun jousitaustan kanssa. On kuin Alistair yrittäisi saada nautintoa objektista, jonka kieltämiseen on tavallaan itse osallistunut. 
Kuten elokuvan alkupuoli jo osoitti, on tämän teeman tuoma nautinto jotain symbolisen järjestyksen kieltämää - objekti on joutunut puutteen dialektiikan uhriksi. Kaikkein selvimmin tämä kielletty nautinto ilmenee pääteeman soidessa sormenleikkuun taustalla. Nautinnon kieltäminen tulee esiin jo siinä, että Adan lähettämä kosketin vertautuu sormeen ${ }^{5}$. Ada siis mutiloi omaa rakastettuaan/rakastajaansa irrottamalla siitä sormen. Kun piano vertautuu tiedostamattomaan ja kun tiedostamaton Lacanin mukaan on olennaisesti symbolisen järjestyksen muodostama, niin elokuva osoittaa tässä sormenleikkuukohdassa vanhan lain: sormi sormesta. Adan sormen leikkaaminen on viimeinen isku, jonka symbolinen järjestys voi antaa pyrkiessään kieltämään Adan yhteisöllisen ulkopuolisen nautinnon. Kohtauksessa musiikki taukoaa vain sormen katkaisuun ja Floran huutoon. Pääteema alkaa uudestaan soida hitaana versiona, kun Ada nousee ylös mudasta ja kääntyy katsomaan Alistairia. Tämä on viimeinen kerta, kun teema esiintyy elokuvassa lukuunottamatta lopputekstien taustalla soivaa musiikkia - lopputekstit loppuvat pääteeman säestyksellä. Alistair (symbolinen, Isä) kieltää avioliiton (symbolisen suhteen) ulkopuolisen nautinnon leikkaamalla Adan sormen. Samalla symbolinen kieltää Adan (ja meidän - ja loppujen lopuksi symbolisen) nautinnon tuosta teemasta. Samalla, kun Alistair leikkaa pois Adan sormen, joka pystyi nostamaan esiin nautintoon johtavan peilin niin pianon soitossa kuin rakastelussa, tämä kielletyn nautinnon teema lakkaa olemasta.

Alun D-duuriteema ei joudu samanlaisen nautinnon kieltämisen uhriksi. Alun jälkeen se esiintyy kaksi kertaa. Ensimmäisellä kerralla se esiintyy, kun Ada alkaa rakastua Georgeen. Tämä tapahtuu, kun Ada vierailee seuraavan kerran Georgen luona sopimuksen teon jälkeen ("One visit for every black key"). Adan lähdettyä musiikki jatkuu hetken aikaa Georgen katsoessa pianoa verhon takaa. Sitten se häivytetään pois ja George pyyhkii pianosta pölyt pois. Teema soi myös taustalla, kun Ada ja George rakastelevat Alistairin todistaessa tapausta seinän raoista. Teema on tavallaan vapaan nautinnon ilmentymä.

"Lads \& Lassies" -teema tuo mielenkiintoisia uusia puolia elokuvaan. Se on jotakin, joka on Adan ja Floran välillä. Ensimmäisen kerran se esiintyy, kun Ada soittaa pöytää ja tytär laulaa sen F-duurissa Alistairin tullessa maakaupoista. Teema kuvastaa mielestäni Adan ja Floran samastumista toisiinsa. Adalle Flora on yksi egon syntyyn johtaneista samastumisista. Adan ja Floran tiet alkavat kuitenkin erota, kun Ada astuu sosiaalisten normien ulkopuolelle Floran yhä pitäessä niistä kiinni. Seuraava Floran laulu onkin "Yorkin herttua", jota hän laulaa pinotessaan Alistairin hakkaamia halkoja. Seuraavan kerran 'Lads \& Lassies" -teema esiintyy kohtauksessa, jossa Ada ja George tekevät sopimuksensa. Ada nimittäin soittaa teeman kehittelyä. Flora ajautuu yhä kauem-

${ }^{5}$ Huomiosta samankaltaisuudesta sormien ja pianonkoskettimien välillä kiitän Anna Kuljua. 
maksi Adasta. Hän harjoittelee kolmatta laulua yhteisön (teatteri-)esitystä varten. Tätä laulua hän hyräilee edelleen esityksen jälkeisellä vierailukerralla Georgen luona, jolloin hän näkee Adan ja Georgen suutelevan.

Musiikin kautta tulkittuna Adan ja Floran tiet tuntuvat todella eroavan, kun piano on tuotu Alistairen talolle. Ada kieltäytyy soittamasta (jakamasta nautinnon lähdettään) Alistairille. Niinpä Flora joutuu soittamaan tälle "Lads \& Lassies" -teemaa. Ada on ikään kuin unohtanut samastumisensa Floraan nyt, kun George on herättänyt hänessä rakkauden. Tämän takia Ada vaeltaa ulos talosta tuijottelemaan metsää. Musiikki siirtyy laulusta kaihoisaan (jo aiemmin kuultuun) saksofonilla soitettuun teemaan samalla, kun kamera kuvaa ensin Adan käsiä selän takana, nousee sitten hänen nutturaansa ja kuvaa lopuksi ikään kuin Adan päässä (pään läpi) riehuvaa tuulista metsää. Adan ja Floran eroa korostaa myös Floran laulama "Yorkin herttua" hänen viedessään koskettimen Alistairille.

Aivan elokuvan lopussa, kun Ada, George ja Flora ovat Nelsonissa, Ada soittaa pianolla "Lads \& Lassies" -teeman. Tämä on mielestäni kuvaus Adan integraatiosta. Ada ja Flora ovat taas samalla puolella. On kuin kuoleman kokemus olisi näyttänyt Adalle eri samastumisensa, joista yksi on Floraan ja "Lads \& Lassies" -teemaan. Kun hän soittaa teeman G-duurista siihen yhdistyy George. Adan eroa aiemmasta nautinnon lähteestä, pianosta korostaa ääni, joka syntyy Adan laskiessa uuden metallisormensa pianonkoskettimelle. Elokuva kuvallistaa Adan ja pianon välillä olevan "klikin". Metallisormen takia Ada ei voi enää saada samanlaista yhteyttä pianoon kuin aiemmin - hän ei voi muodostaa käsillään akustista peiliä itsensä ja pianon välille. Edellisen kohtauksen reaalisen lähelle tulo saa esiin mustan aukon avulla eri samastumiset samaan aika-avaruuteen. Tätä korostaa vielä mielestäni lopputekstien alkupuolella soiva "Lads \& Lassies" -teema. Nyt siihen on yhdistetty erilainen jousitausta kuin aiemmin. Samoin teema esiintyy kahtena eri versiona päällekkäin: hitaampana alkuperäisenä versiona ja nopeampana minimalistisena kehittelynä, jota Ada soitti Georgelle. Mitä kaunein "happy end".

Pianossa on useita kohtia, joissa aika ja tila vääristyvät. Nämä voidaan suurimmaksi osaksi selittää objet $a$ :n läheisyyden mustana aukkona eli reaalisen kohtaamisen avulla. Ensimmäinen on alkupuolen kohtaus, jossa piano on jätetty yksin rannalle. Samalla kun pääteemasta rakennetaan kielletty nautinto, kamera kuvaa laajakulmassa rannalle jäänyttä pianoa. Sitten kamera ajaa hitaasti vasemmalle pitäen Adan kasvot lähikuvassa. Tämä on melko pitkä otos. Koska kameran liike on hidas, tausta näyttää liikkuvan hitaasti vasemmalle aivan kuin kuvaa olisi hidastettu - mitä se ilmeisesti ei ole. Seuraavassa otoksessa näkyy laajakulmassa Ada ja Flora katsomassa rantakalliolla pianoa kantajien kulkiessa heidän ohitseen normaalinopeudella. Tämän jälkeen on tilallinen ja ajallinen siirtymä. Pääteeman siivittämänä kamera lentää hieman hidastettuna yli sademetsän. Näin siis pääteemasta rakennettu objet $a$ vääristää aikaa toisessa otoksessa ja lentokuvissa. 
Seuraavan kerran tilan vääristymisen tuntu tulee, kun Ada repii hääpuvun yltään ja ryntää ikkunaan katsomaan ulos sateeseen. Pääteeman soidessa kuvataan ensin Adan kasvoja talon ulkopuolelta sisään, sitten näytetään yksinäistä pianoa myrskyisellä rannalla. Molemmat otokset ovat normaalinopeudella kuvattuja, mutta musiikki luo tilallisen jatkuvuuden. Musta aukko, objet a saa nämä kaksi tilaa yhtymään.

Seuraava pääteeman esiintyminen antaa samanlaisen tunteen tilan vääristymisestä. Pääteema alkaa soida hieman ennen ajallista ja tilallista siirtymää Georgen kodin pihalta rannalle, johon hän suostunut Adan ja Floran viemään. Rannalla kamera ajelee hitaasti henkilöstä toiseen kuvaten Adan nautintoa akustisen peilin rakennuksessa. Musiikki toimii myös siltana ajallisessa hyppäyksessä rannalla olon aikana. Siirryttäessä pääteeman variaatiosta takaisin sen perusmuotoon onkin yhtäkkiä ilta. Näin kaksi tilaa ja kolme eri aikaa sulautuvat yhdeksi jatkumoksi.

Hidastettua kuvaa on käytetty, kun kuvataan Alistairin päätöstä vaihtaa piano maa-alueeseen. Lyhyessä hidastetussa kuvassa näkyy, kuinka kirves iskeytyy pölliin. Aiheuttaako pianon puheena oleminenkin tällaisia ajan vääristymiä? Kuva on tietenkin enteellinen tulevasta sormen hakkuusta. Kirveen tulevaa kauhua korostaa jonkin linnun varoitushuuto, joka kaikuu kirveen iskeytyessä pölliin. Mutta toisaalta Alistairin päätös vaihtaa piano maa-alueeseen voidaan nähdä myös osoituksena pianomusiikin tuottaman nautinnon kaihtamisesta. Tuo nautinto pitää siirtää toiseuteen - se ei sovi Isän lain alueelle.

Samanlainen hidastus pääteeman yhteydessä tulee, kun Ada palaa metsän halki Georgen luota ja Alistair on häntä vastassa. Kun Alistair hyppää esiin puun takaa on lähikuva kasvoista hidastettu. Samalla kuuluu linnun varoitushuuto, kuten edellisen kerran kirveen iskuun liitettynä. Alistairista leikataan hidastettuihin Adan kasvoihin. Adan kävellessä pakoon kuvanopeus on normaali. Adan rimpuillessa vapaaksi Alistairin otteesta on kuvaa jälleen hidastettu. Samoin on kuvia Adan takertumisesta ohuisiin puunrunkoihin, Alistairin kouraisua Adan jalkovälistä ja rämpimistä ryteikössä hidastettu. Floran huuto katkaisee tämän ajallisen vääristymän. Flora siis palauttaa Alistairin ja Adan todellisuuteen (symboliseen). Alistair itse on työntänyt pääteeman nautinnon symbolisen toiseuteen, joten pyrkiessään sitä kohti, kohti Adaa, he molemmat joutuvat objet a:n mustana aukkona vaikutuksen alaisiksi.

Mielenkiintoinen tilan vääristymä on kohta, jossa Flora vie Alistairille pianonkoskettimen. Pianonkosketin on kuin pala reaalista, joka pystyy vääristämään perspektiiviä. Kohtauksen kuvakulmat ovat nimittäin poikkeuksellisia muuhun elokuvaan verrattuna. Tästä kohtauksesta alkaa myös pääteeman viimeinen esiintyminen. Musiikki siivittää Alistairin ja Floran matkan metsän halki. Kuvat ovat ilmeisesti normaalinopeudella, mutta nopea kameran liike sen seuratessa Alistairia saa aikaan vauhdin tunnun. Sisällä talossa Ada lukee kirjaa, kun Alistair hyökkää kirveineen sisään. Osa kuvista on hidastettuja, kuten esimerkiksi kuva pöydällä olevasta kirjasta, joka lentää kirveeniskun voimasta 
ilmaan. Kirveen tipahtaminen on myös hidastettu. Linnun varoitushuuto on korvautunut tässä Floran huudolla. Nyt kun pääteema objektina ja siitä saatavan nautinnon lopullinen kieltäminen ovat lähimmillään (iskun jälkeen), kuvataan Adaa hidastettuna pitkä tovi. Ada ei luovu nautinnosta eikä huuda. Floran toinen huuto "Mother!" palauttaa jälleen normaalinopeuden.

Poikkeuksena säännöstä on kuva ryteikköisestä metsästä, jossa kamera ajaa hitaasti vasemmalle. Kuva sijoittuu Floran sormen viemisen ja Adan puhumisen Alistairille väliin. Taustalla voi kuulla klarinetin ja jousten soittamaa melodiaa etualalle nostetun sirkkojen sirityksen kanssa. Edellisessä kohtauksessa George on ymmärtänyt, ettei hän voi estää Alistairia tuhoamasta Georgelle rakasta objektia, Adaa ja tämän nautintoa tuottavia käsiä. Vaikka kuva metsästä ei luultavasti ole hidastettu, saa musiikki jälleen aikaan tunteen ajan pysähtymisestä. Vaikutelma johtunee osaltaan herätetystä avuttomuuden tunteesta. Toisaalta tässä voidaan nähdä lacanilaisittain se, kuinka objet $a$ kääntää subjektin ja objektin suhteen - subjektista tuleekin objekti, katsojasta katsottu kuva (Lacan 1977b, 106). Lacanille nautinnon lähde on objet $a$ - peilissä havaittu kokijaa täydellisempi objekti. Juuri tämä täydellisyys aiheuttaa lamaannuksen, se tuhoaa subjektiuden ja hajottaa egon samastumiset erilleen. Georgelle Adan käsistä muodostuu nautinnollinen objekti, kun ne pyritään erottamaan hänestä. Näin mahdottomuus tehdä mitään Adan sormien pelastamiseksi on osaltaan reaalisen kauhistuttavuuden näyttäytymistä. Ajatus nautinnon lähteen tuhoamisesta tuo objet a:n lähelle ja lamauttaa Georgen.

Viimeiset hidastetut kuvat liittyvät lähinnä Adan reaalisen kohtaamiseen. Hänen vajotessaan pianon vetämänä meren syvyyteen osa kuvista on hidastettuja. Toisaalta myös kuvaus veden alla tuo mukanaan hitautta veden nestemäisyyden takia. Hidastetut kuvat ovat kenties koko elokuvan hitaimmat, mutta niin on reaalinenkin lähimpänä ainakin Adaa tuolla hetkellä. Hidastettuja ovat myös Adan pintaan nousu ja hänen nostamisensa veneeseen. Reaalisen tullessa lähelle pääsee esiin voimakkaimmin pianon lalangue, mutta myös Adan sisäinen, "mielen ääni". Kuva Florasta heittämässä kärrynpyöriä Nelsonissa on hidastettu. Tämä liittyy mielestäni Adan, Georgen ja Floran saavuttamaan nautinnolliseen yhteyteen. Ada soittaa Floran teemaa Georgen sävellajissa. Elokuva kertoo mahdollisesti näiden kolmen muodostaman yhteisön yhteisestä nautinnosta. Ehkä se pyrkii osoittamaan, että yhteisöllinen nautinto olisikin mahdollista, vaikka lacanilainen psykoanalyysi ei näe sitä mahdolliseksi. Elokuvan viimeinen kuva vaikuttaa hidastetulta johtuen veden jähmeydestä. Kuvassa on kuitenkin piano, joka myös aiheuttaa hitauden oman painonsa avulla.

Elokuvassa on monia kohtia, joissa musiikki tai muut äänet toimii sitovana elementtinä siirryttäessä tilasta ja ajasta toiseen. Nämä ovat kuitenkin enemmän perinteisiä elokuvallisia yhtenäisyyden luomisen keinoja, joten en puutu niihin. Myös kameran liikkeet ovat samantapaisia niin edellä kuvatuissa kuin joissakin muissakin kohdin, mutta yritin keskittyä niihin, jotka mielestäni olivat keskeisiä työni ja teorioiden kannalta. 


\section{Lopuksi}

Mielestäni lacanilaiset teoriat siitä, miten reaalisen läheisyys vaikuttaa kokemiseen, toimivat hyvin elokuvan Piano yhteydessä. Elokuvan pääteema on kenties kaikkein tärkein reaalista lähestyttäessä. Elokuva rakentaa siitä objet petit $a: n$, joka pystyy vaikuttamaan niin aikaan kuin tilaan. Nämä muutokset ilmenevät lähinnä hidastuskuvina. Toisaalta myös musiikin läsnäolo on omiaan aiheuttamaan ajan ja tilan muutoksen tunnun tai jopa luomaan jatkuvuutta näiden välille.

\section{Tutkimusmateriaali}

Piano (The Piano). Holly Hunter (Ada), Harvey Keitel (George Baines), Sam Neill (Alistair Stewart), Anna Paquin (Flora), et al. Written and directed by Jane Campion. Music by Michael Nyman. Editor: Veronica Janet. Director of photography: Stuart Dryburgh. Executive producer for Ciby 2000: Alain Depardieu. Produced by Jan Chapman. Miramax Films 1992, New Zealand. $116 \mathrm{~min}$.

\section{Lähteet}

Botting, Fred 1994. Relations of the Real in Lacan, Bataille and Blanchot. SubStance. A Review of Theory and Literary Criticism, 73: 24-40.

Cusick, Suzanne G. 1994. On a Lesbian Relationship with Music. A Serious Effort Not to Think Straight. In Queering the Pitch. The New Gay and Lesbian Musicology, ed. by Philip Brett, Elizabeth Wood and Gary C. Thomas. New York and London: Routledge.

Hawking, Stephen W. 1988. Ajan lyhyt historia. Alkuräjähdyksestä mustiin aukkoihin. Suom. Risto Varteva. Porvoo, Helsinki ja Juva: Werner Söderström Osakeyhtiö.

Hietala, Veijo 1990a. Lacanilainen psykoanalyysi ja elokuvanteoria. Teoksessa Elokuvanteoria historia. Artikkelikokoelma, toim. Raimo Kinisjärvi, Matti Lukkarila ja Tarmo Malmberg. 2. korjattu painos. Helsinki: Like.

Hietala, Veijo 1990b. Situating the Subject in Film Theory. Meaning and Spectatorship in Cinema. Turun yliopiston julkaisusarja B, osa 194. Turku: Turun yliopisto.

Ihanus, Juhani 1995. Toinen. Kirjoituksia psyykestä, halusta ja taiteista. Jyväskylä: Gaudeamus.

Lacan, Jacques 1977a. Écrits. A Selection. Trans. by Alan Sheridan. New York and London: W. W. Norton \& Company. 
Lacan, Jacques 1977b. The Four Fundamental Concepts of Psychoanalysis. [The Seminar of Jacques Lacan. Book XI. 1964]. Ed. by Jacques-Alain Miller. Trans. by Alan Sheridan. Reprinted with an Introduction by David Macey 1994. London, New York, Ringwood, Toronto and Auckland: Penguin Books.

Lacan, Jacques 1982. The Phallic Phase and the Subjective Import of the Castration Complex. In Feminine Sexuality. Jacques Lacan and the école freudienne, ed. by Juliet Mitchell and Jacqueline Rose. Trans. by Jacqueline Rose. Houndmills and London: The Macmillan Press Ltd.

Lacan, Jacques 1988a. The Seminar of Jacques Lacan. Book I. Freud's Papers on Technique 1953-1954. Ed. by Jacques-Alain Miller. Trans. by John Forrester. Cambridge, New York, New Rochelle, Melbourne and Sydney: Cambridge University Press.

Lacan, Jacques 1988b. The Seminar of Jacques Lacan. Book II. The Ego on Freud's Theory and in the Thechnique of Psychoanalysis 1954-1955. Ed. by Jacques-Alain Miller. Trans. by Sylvana Tomaselli. Cambridge, New York, New Rochelle, Melbourne and Sydney: Cambridge University Press. Metz, Christian 1990. Psychoanalysis and Cinema. The Imaginary Signifyer. Ed. by Stephen Heath and Colin MacCabe. Trans. by Celia Britton, Annwyl Williams, Ben Brewster and Alfred Guzzetti. London: Macmillan Academic and Professional Ltd.

Rose, Jacqueline 1982. Introduction - II. In Feminine Sexuality. Jacques Lacan and the école freudienne, ed. by Juliet Mitchell and Jacqueline Rose. Trans. by Jacqueline Rose. Houndmills and London: The Macmillan Press Ltd.

Rosolato, Guy 1974. La voix: Entre corps et langage. Revue Francaise de Psychanalyse, XXXVIII: 75-94.

Žižek, Slavoj 1992. Enjoy Your Symptom! Jacques Lacan in Hollywood and out. New York and London: Routledge.

Žižek, Slavoj 1991. Lookin Awry. An Introduction to Jacques Lacan through Popular Culture. Cambridge, Massachusetts and London: The MIT Press. 